\title{
Paraconodont Westergaardodina in the Lower Ordovician of the Prague Basin, Czech Republic
}

\author{
MICHAL MERGL
}

\begin{abstract}
The morphology of elements of the paraconodont genus Westergaardodina found in the Early Ordovician deposits of Bohemia resembles that of the Late Cambrian species W. bicuspidata and W. polymorpha. The presence of Westergaardodina is consistent with the suggested Upper Tremadocian age of its horizon, as reworking of the Upper Cambrian sediment seems unlikely for geological and taphonomic reasons. This is the first report of this genus from the Ordovician in the European part of peri-Gondwana. - Key words: Paraconodonta, Westergaardodina, Ordovician, Tremadocian, Prague Basin, Czech Republic.
\end{abstract}

MERGL, M. 2006. Paraconodont Westergaardodina in the Lower Ordovician of the Prague Basin, Czech Republic. Bulletin of Geosciences 81(4), 305-308 (2 figures). Czech Geological Survey, Prague. ISSN 1214-1119. Manuscript received January 23, 2006; accepted in revised form October 12, 2006; issued December $31,2006$.

Michal Mergl, University of West Bohemia, Department of Biology, Klatovská 51, 30619 Plzeň, Czech Republic; mmergl@kbi.zcu.cz.

The genus Westergaardodina Müller, 1959 represents a separate branch of the paraconodonts. Many distinctive characteristics make it an easily distinguishable genus among Cambrian and early Ordovician conodonts. This genus is known from many sites of latest Middle Cambrian to Middle Ordovician age around the world, for instance in Scandinavia and Poland (Müller 1959, Szaniawski 1971, 1980, Bednarczyk 1979, 1997, Popov et al. 1989, Müller \& Hinz 1991, Dzik et al. 1994), Australia (Druce \& Jones 1971), China (Nogami 1966, Dong et al. 1991, 2004), America (Fortey et al. 1982), Kazakhstan (Abaimova 1983, Baitorina 1983), and Iran (Müller 1973). In the European part of peri-Gondwana, this genus has not been reported except for unpublished data from the Klabava Formation (Floian), Prague Basin (Jaroslava Zusková, pers. comm.).

Four elements of Westergaardodina have recently been observed with associated microfossils in the lower Klabava Formation (Olešná Member). The material was collected near the small village of Těně in the Komárov area (SW part of the Prague Basin, Czech Republic), a locality described by Mergl (1986). Organic-walled and calcareous-shelled index fossils, such as chitinozoans or graptolites, are absent in the reddish siltstones of the Olešná Member. Although the four imperfectly preserved paraconodont elements are not sufficient for critical comparison with other published records, or for stratigraphical and palaeogeographical correlations, the occurrence of this genus in the Prague Basin is worth reporting because it may initiate further conodont study in that region.

\section{Geological setting}

The Westergaardodina elements were found in the Olešná Member of the Klabava Formation at the Těně (west) locality, at a level $3.5 \mathrm{~m}$ above the boundary between the Mílina and Klabava Formations. This level (Mergl 1986; unit H), which contains phosphatic-clay clasts in a greywacke bed, is widespread in the Komárov area (Mergl 1986) and has yielded a rich fauna of sponges and organophosphatic brachiopods. The Mílina/Klabava boundary is marked by the disappearance of the cherts of the Mílina Formation, while the Klabava Formation is succeeded by a lithologically uniform sequence $(20-30 \mathrm{~m})$ of red-brown siltstones, silty shales, and thin beds of fine-grained greywackes. This lithological boundary has been formally taken as the Tremadocian/Floian (= Lower Arenigian) boundary in the Prague Basin (Fig. 1) (Havlíček \& Vaněk 1966).

\section{Material and methods}

The Westergaardodina elements and other associated microfossils were isolated from phosphatic-clay clasts $(1-2 \mathrm{~cm}$ in size) by a dilute $(\sim 10 \%)$ hydrochloric acid, and were repeatedly washed and picked under a binocular microscope. Only four paraconodont elements were found among the thousands of sponge spicules and brachiopod shells. These four elements are satisfactorily preserved but lack some details. The associated organophosphatic brachiopods are remarkably well preserved (Mergl 2002), although their original shell has been partially replaced by silica, leaving small empty spaces between thin external and internal silica sheets. The siliceous sponge spicules are well-preserved (Mergl \& Duršpek 2006). The degree of preservation of the Westergaardodina elements is somewhat puzzling: they show a similar mode of preservation as the brachiopod shells, but other conodonts are absent. This absence is perhaps due to the destruction of euconodonts 


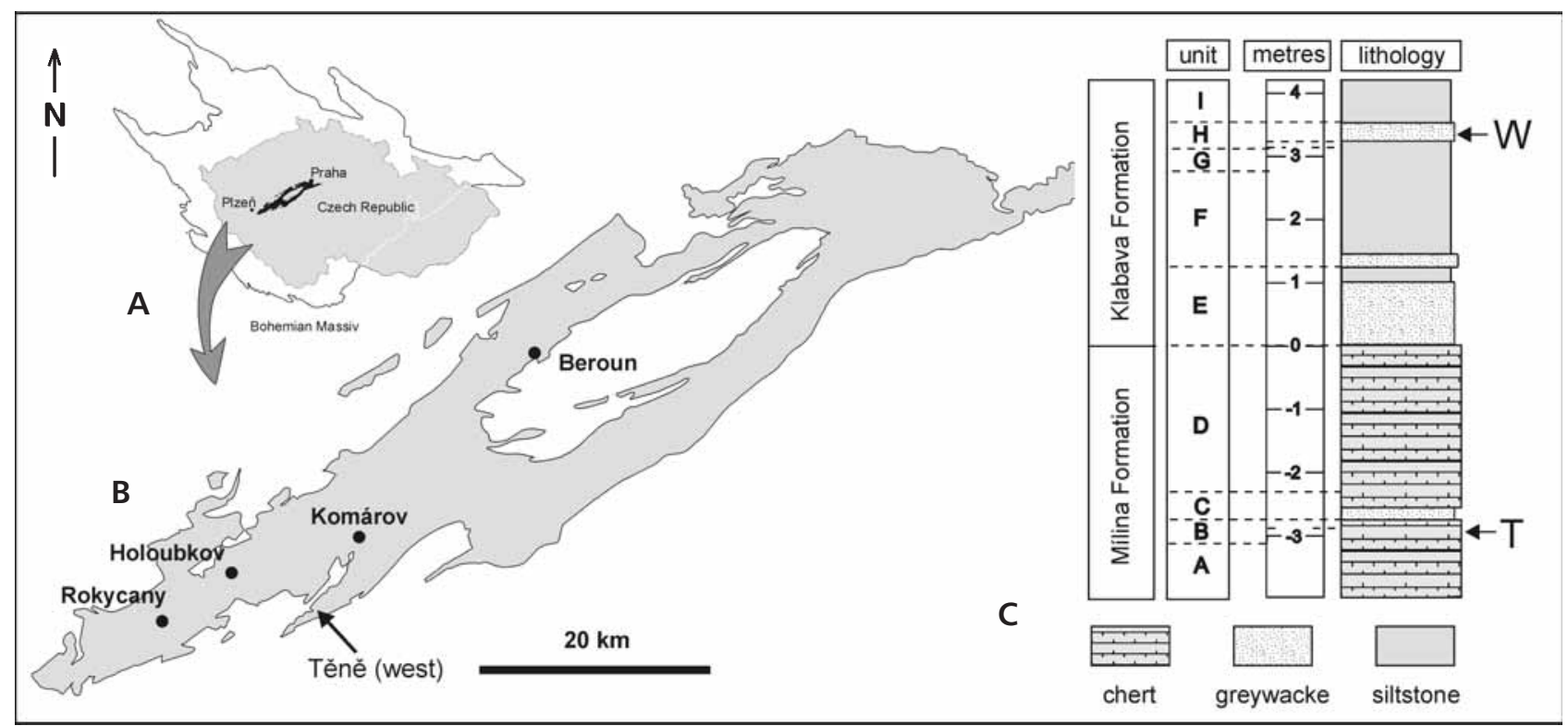

Figure 1. A - map of the Bohemian Massif showing the Czech Republic and the Ordovician of the Prague Basin. • B - Ordovician of the Prague Basin; arrow indicates the Těně locality. $\bullet \mathrm{C}$ - lithology of the boundary interval between the Mílina/Klabava formations at the Těně locality. $\bullet$ W - horizon containing Westergaardodina cf. bicuspidata Müller, 1959.・T - horizon containing Thysanotos siluricus (Eichwald, 1840).

from etching by hydrochloric acid. The same phosphaticclay clasts yielded highly fragmental and poorly preserved simple-cone euconodont elements after etching by hydrofluoric acid. Similar selective destruction of euconodont elements has been reported in chalcedonites of Tremadocian age from the Holy Cross Mountains, Poland (Szaniawski 1980).

The material is stored in the palaeontological collections of the University of West Bohemia, Plzeň (PCZCU).

\section{Age of Westergaardodina elements}

The paraconodont Westergaardodina is a typical component of the phosphatic microfauna from the late/middle Cambrian to the early Ordovician; the youngest elements referred to this genus are reported from the Middle Ordovician. The genus is almost cosmopolitan, but collecting methods have biased reports of its occurrence, as it has rarely been described from lithified siliciclastic sediments (Bulman \& Rushton 1973). Most of the published data about its occurrence comes from limestones in Scandinavia, Poland, Kazakhstan, China and Australia, but it has not been reported from the predominantly siliciclastic successions of peri-Gondwanan Europe.

Upper Cambrian marine sediments are unknown in the Barrandian area, where terrestrial (river and lake) deposits with contemporaneous subaerial volcanism occurred during the Late Cambrian (Havlíček 1992). Consequently, the release of the paraconodont elements from Cambrian sediments during the early Ordovician seems unlikely. The lack of any phosphatic brachiopods and other paraconodonts characteristic of the Late Cambrian, and the same mode of preservation of brachiopod shells and paraconodont elements, suggest the same age for all fossils present in the phosphatic-clay clasts. Post-Tremadocian reports of Westergaardodina are rare (Dzik 1976, Dzik et al. 1994), but the genus is fairly common in the Tremadocian. Bohemian finds of Westergaardodina Müller, 1959 occur above a distinct Upper Tremadocian trilobite fauna (equivalent of the Ceratopyge-fauna; Mergl 1994, 2006) and below the horizon containing Clonograptus sp. (Kraft \& Mergl 1979), which is approximately equivalent to the Tetragraptus approximatus Biozone. The stratigraphically and palaeogeographically important lingulate brachiopod Thysanotos siluricus (Eichwald, 1840) occurs cca $5.5 \mathrm{~m}$ below the Westergaardodina-bearing bed, in the upper part of the Mílina Formation. This brachiopod is a characteristic element of the Hunneberg stage fauna in Baltoscandia and the southern Urals (Gorjansky 1969, Popov \& Holmer 1994, Bednarczyk 1999). However, its FAD in Central Europe preceded Baltic occurrences (Sdzuy 1955, Mergl 1997). Trilobites associated with $T$. siluricus are closely related to those of the Bjørkåsholmen Formation of Scandinavia, though they might have a slightly younger age. Consequently, the Westergaardodina bearing-bed is definitely the Upper Tremadocian age and falls in the upper part of the $P$. deltifer Biozone or in the P. proteus Biozone. It is unlikely, that the lithological boundary between the Mílina Formation and Klabava Formation (Olešná Member) is equivalent of the Tremadocian/Floian boundary as suggested by previous authors (Havlíček \& Vaněk 1966 and others). 


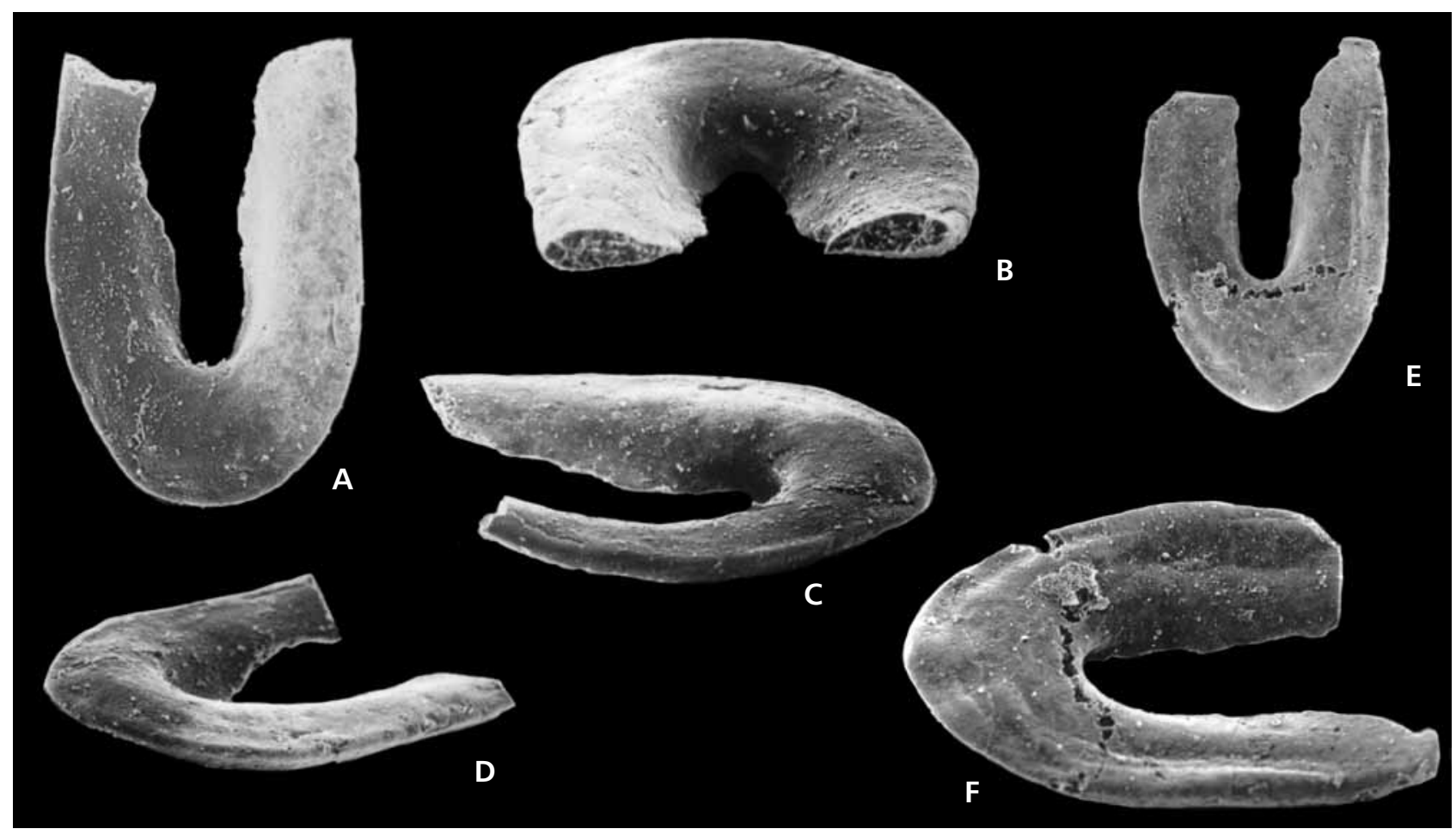

Figure 2. Westergaardodina cf. bicuspidata Müller, 1959. • A-D - specimen PCZCU 1670, anterior and oblique views, 150×, 230×, 150×, and 130×. • E, F - specimen PCZCU 1671, anterior and oblique views, 100x, 130x.

\section{Systematic palaeontology}

Order Paraconodontida Müller, 1962

\section{Genus Westergaardodina Müller, 1959}

Type species. - Westergaardodina bicuspidata Müller, 1959; Upper Cambrian; erratic material from Scandinavia, Germany.

\section{Westergaardodina cf. bicuspidata Müller, 1959}

Figure 2A-F

Material. - Four elements, PCZCU 1670, 1671, 1680, 1681.

Description. - Sclerite bicuspidate, gently recurved. Lateral projections extend from the subcircular lower part of element. Lateral projections almost parallel, slightly converging toward top ends. Basal rim narrow, weakly defined. Median projection absent.

Remarks. - All specimens from Bohemia have a uniform morphology and fall within the variation range of the type species. However, in the Bohemian specimens the keeled median projection is not preserved, the lateral cavity in lateral projections are missing, and the transverse profile of the lateral projections is less convex than in W. bicuspidata Müller, 1959. The sizes of the Bohemian specimens are about $300-350 \mu \mathrm{m}$, which is near the lower size range of the specimens from Scandinavia. The similarly shaped W. polymorpha Müller \& Hinz, 1991 also lacks the median projection, but its basal portion is much larger than that of the Bohemian specimens. The Bohemian specimens may represent a separate species, possibly derived from W. polymorpha, but the formal description of a new taxon cannot be based on these few elements.

Occurrence. - Těně (west) at Komárov, Prague Basin; Klabava Formation, Olešná Member; Early Ordovician, Upper Tremadocian.

\section{Acknowledgements}

The author is indebted to Jana Nebesářová from the Academy of Sciences of the Czech Republic at České Budějovice for help with the SEM work. This research was supported by the Grant Agency of the Czech Republic: grant 205/03/0670 "Fauna and Stratigraphy of the Tremadocian in Bohemia". It is a contribution to IGCP Project 503 "Early Palaeozoic Palaeogeography and Palaeoclimate". Thanks are also due to Stig M. Bergström, Jerzy Dzik and Hubert Szaniawski, who kindly provided constructive review comments. 


\section{References}

ABAimova, G.P. 1983. Konodonty i drugie problematitscheskiye ostatki srednego-verchnego kembrija Malogo Karatau, 96-104. In APPOLONOV, M.K., BANDALETOV, S.M. \& IVSHIN, N.K. (eds) Stratigrafiya i paleontologiya nizhnego paleozoya Kazakhstana. Izdatelstvo Nauka Kazakhskoy SSR, Alma-Ata.

BAITORINA, T.B. 1983. Nekotoryie konodonty verchnego kembriya i nizhnego ordovika iz stratotipitscheskogo razreza $r$. Kirshabakti v Malom Karatau, 104-110. In APPOLONov, M.K., BANDALETOV, S.M. \& Ivshin, N.K. (eds) Stratigrafiya $i$ paleontologiya nizhnego paleozoya Kazakhstana. Izdatelstvo Nauka Kazakhskoy SSR, Alma-Ata.

BEDNARCZYK, W. 1979. Upper Cambrian to Lower Ordovician conodonts of Leba elevation, NW Poland, and their stratigraphic significance. Acta Geologica Polonica 29(4), 409-422.

BEDNARCZYK, W. 1997. Ordovician conodont biostratigraphy of the Polish part of the Baltic Syneclise. Palaeontologia Polonica 58, 107-121.

BEDNARCZYK, W. 1999. Significance of the genus Thysanotos Mickwitz, 1896 for the Ordovician stratigraphy of East-Central Europe. Bulletin of the Polish Academy of Sciences, Earth Sciences 47(1), 15-25.

Bulman, O.M.B. \& Rushton, A.W.A. 1973. Tremadoc faunas from boreholes in Central England. Geological Survey of Great Britain, Bulletin 43, 1-40.

Dong, X.-P. \& BergströM, S.M. 2001. Middle and Upper Cambrian protoconodonts and paraconodonts from Hunan, South China. Palaeontology 44, 949-985.

Dong, X.-P., RePETSKI, J.E. \& BergströM, S.M. 2004. Conodont biostratigraphy of the middle Cambrian through lowermost Ordovician in Hunan, South China. Acta Geologica Sinica 78(6), 1185-1206.

DRUCE, E.C. \& JonES, P.J. 1971. Cambro-Ordovician conodonts from the Burke River structural belt Queensland. Bureau of Mineral Resources, Geology and Geophysics, Bulletin 110, 1-159.

DZIK, J. 1976. Remarks on the evolution of Ordovician conodonts. Acta Palaeontologica Polonica 23, 51-72.

DZIK, J., OlEMPSKA, E. \& PISERA, A. 1994. Ordovician carbonate platform ecosystem of the Holy Cross Mountains. Palaeontologia Polonica 53, 1-318.

EICHWALD, E. 1840. Über das silurische Schichten-System von Esthland. 210 pp. St. Petersburg.

Fortey, R.A., Landing, E. \& Skevington, D. 1982. Cambrian-Ordovician boundary section in the Cow Head Group, Western Newfoundland, 95-129. In BASSETT, M.G. \& DEAN, W.T. (eds) The Cambrian-Ordovician boundary: sections, fossil distributions, and correlations. National Museum of Wales, Geological Series 3.

GORJANSKY, V.J. 1969. Bezzamkovyje brachiopody kembriyskich i ordovikskich otlozheniy severo-zapada Russkoj platformy. Ministerstvo geologii RSFSR, Severo-zapadnoye territorialnyje geologitcheskoye upravleniye 6, 3-176.

HAVlíČEK, V. 1992. Př́bramsko-jinecká pánev, 19-38. In ChlupÁč, I., HAVlíčEK, V., KŘíž, J., KuKAL, Z. \& ŠTORCH, P. Paleozoikum Barrandienu (kambrium-devon). Český geologický ústav, Praha.
HAVLíčEK, V. \& VANĚK, J. 1966. The biostratigraphy of the Ordovician of Bohemia. Sborník geologických věd, Paleontologie 8, 7-69.

Kraft, J. \& Mergl, M. 1979. New graptolite fauna from the Klabava Formation (Arenig) of the Ordovician of Bohemia. Věstník Ústředního ústavu geologického 54, 291-295.

Mergl, M. 1984. Fauna of the Upper Tremadocian of central Bohemia. Sborník geologických věd, Paleontologie 26, 9-46.

Mergl, M. 1986. The Lower Ordovician (Tremadoc-Arenig) Leptembolon Community in the Komárov area (SW part of the Prague Basin; Bohemia). Folia Musei rerum naturalium Bohemiae occidentalis, Geologica 24, 1-34.

Mergl, M. 1994. Trilobite fauna from the Třenice Formation (Tremadoc) in Central Bohemia. Folia Musei rerum naturalium Bohemiae occidentalis, Geologica 39, 1-31.

Mergl, M. 1997. Distribution of lingulate brachiopod Thysanotos in Central Europe. Věstník Českého geologického ústavu $72(1), 27-35$.

MERGL, M. 2002. Linguliformean and craniiformean brachiopods of the Ordovician (Třenice to Dobrotivá Formations) of the Barrandian, Bohemia. Acta Musei nationalis Pragae, Series $B$ 58(1-2), 1-82.

Mergl, M. 2006. Tremadocian Trilobites of the Prague Basin, Czech Republic. Acta Musei nationalis Pragae, Series B 62(1-2), 1-70.

MERGL, M. \& DURŠPEK, J. 2006. Sponge spicules and radiolarians from the Olešná Member of the Klabava Formation (Ordovician, Prague Basin, Czech Republic). Bulletin of Geosciences 81(1), 17-26.

MülleR, J.K. 1959. Kambrische Conodonten. Zeitschrift der Deutschen Geologischen Gesellschaft 111, 434-485.

MüLLER, J.K. 1973. Late Cambrian and early Ordovician conodonts from northern Iran. Geological Survey Iran, Reports 30, $1-76$.

MülleR, J.K. \& HinZ, I. 1991. Upper Cambrian conodonts from Sweden. Fossils and Strata 28, 1-153.

NoGAmI, Y. 1967. Kambrische Conodonten von China, Teil 1, Conodonten aus den oberkambrischen Kushan-Schichten. Memoirs of the College of Science, Series B 33, 211-218.

PoPOV, L.E. \& HolmER, L. 1994. Cambrian-Ordovician lingulate brachiopods from Scandinavia, Kazakhstan, and South Ural Mountains. Fossils and Strata 35, 1-156.

Popov, L.E., KhaZANovitch, K.K., Borovko, N.G., SERGEEVA, C.P. \& SobOLEVSKAYA, R.F. 1989. Opornyje razrezy i stratigraphia kembro-ordovikskoj fosforitonosnoj obolovoj tolstchi na severo-zapade Russkoj Platformy. Academy of Sciences of the USSR, Ministry of Geology of the USSR, Transactions 18, $1-222$.

SDZUY, K. 1955. Die Fauna der Leimitz Schiefer (Tremadoc). Abhandlungen der Senckenbergischen Naturforschenden Gesellschaft 492, 1-74.

SZANiAwSKI, H. 1971. New species of Upper Cambrian conodonts from Poland. Acta Paleontologica Polonica 16(4), 401-413.

SzANIAwsKi, H. 1980. Conodonts from the Tremadocian Chalcedony Beds, Holy Cross Mountains (Poland). Acta Palaeontologica Polonica 25(1), 101-121. 